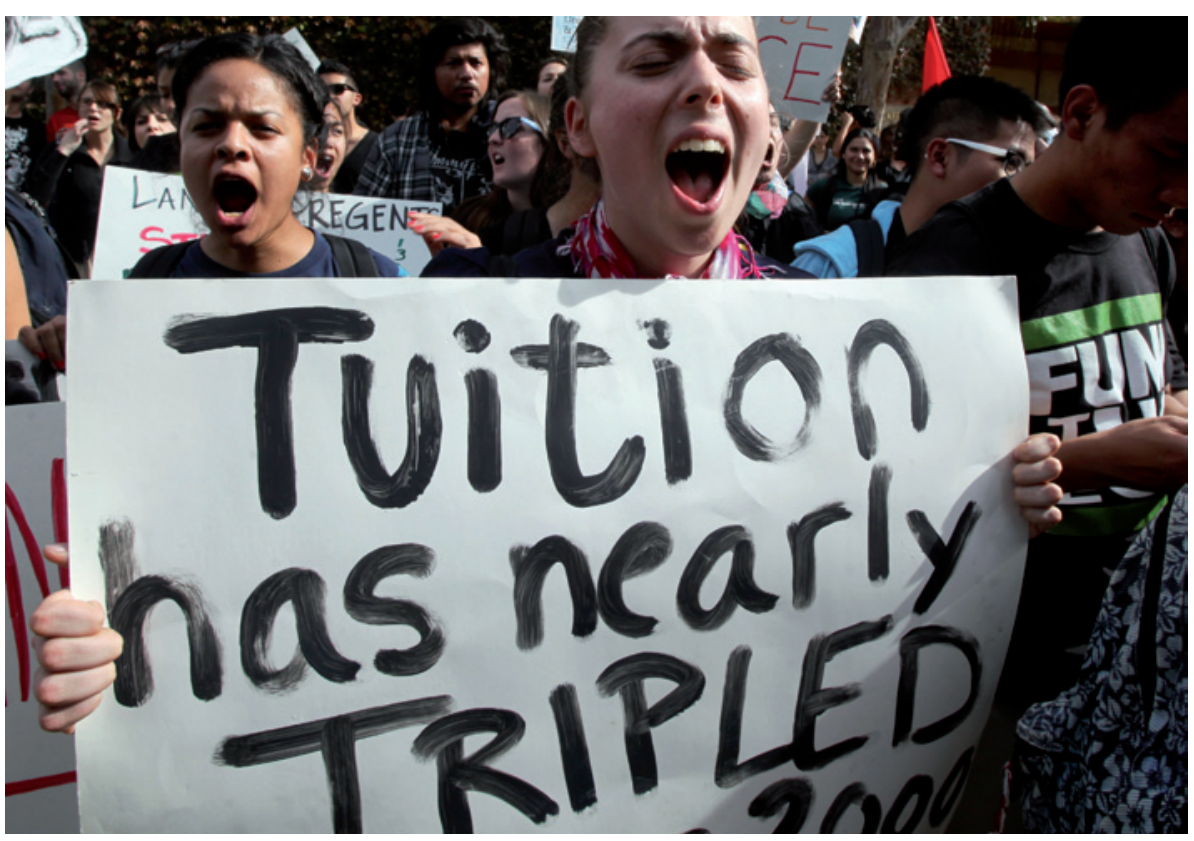

Student protesters disrupted board meetings at the University of California in November.

EDUCATION

\title{
State cuts fuel California protests
}

\section{Fears raised of lasting damage to public university system.}

\section{BY ERIKA CHECK HAYDEN}

$\mathrm{R}$ educed services. Shrinking programmes. Rising tuition fees. These are the signs of an ever more dire budget situation at the University of California, which has suffered years of state funding cutbacks.

Discomfort spread to the boardroom on 28 November, when student protesters at four campuses temporarily shut down a teleconference of the University of California regents, the body that sets policy and budgets for the tencampus statewide system. The protests were sparked in part by an incident on 18 November, in which a policeman at the Davis campus doused student protesters in pepper spray, but the latest grievances also included ongoing hikes in undergraduate tuition fees, which have risen by $71 \%$ since 2008 , and budget cuts that could reach US\$750 million this year.

One of the world's leading public universities, the University of California system is reeling from the impact of the global financial crisis, decades of declining public support for education and a state budget crisis, says John Douglass, a higher-education researcher at the University of California, Berkeley. "The great recession has been a huge blow after a million small cuts, and now you're seeing a transformation of the funding model," he adds. The system increasingly relies on tuition fees, says Douglass. This year, for the first time, the University of California drew more of its funding from private sources, including fees, than from the state (see 'Getting less for more'). California now provides just $11 \%$ of the university's $\$ 22.5$-billion budget, down from $30 \%$ in the 1980 s.

\section{GETTING LESS FOR MORE}

Despite tuition-fee increases, spending per student at the University of California (UC) is now about $80 \%$ of what it was in 1990, owing to falling state funding.

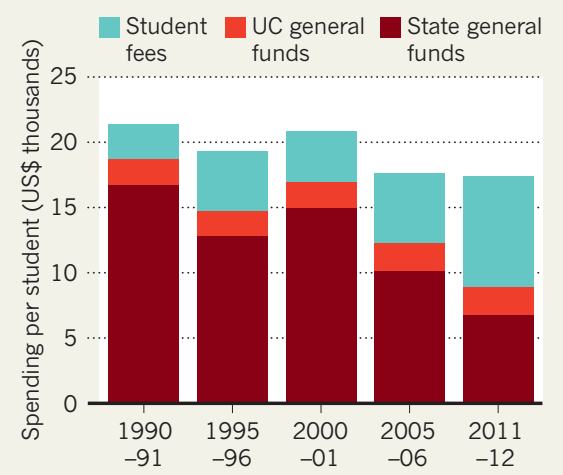

Undergraduates have borne the brunt, facing higher fees, fewer courses and larger class sizes. Scientific researchers are less directly affected because they get much of their funding from federal grants and private foundations. But they are also feeling the effects of the $\underset{\sim}{\sim}$ squeeze as graduate students face constraints on resources and time, and campus services and maintenance are cut.

Philippe Marchand, a graduate student in environmental science and policy management at Berkeley, needs to increase the amount of paid teaching he does to cover his tuition fees. But teaching budgets across the system have fallen, so fewer teaching slots are available, and he is unsure whether the option will be available next semester. But even if he can teach, it will not solve his problems. "I'm going to have to make some difficult choices; if I have to teach every semester I may have to suspend my research," he says. Since 2006, the number of graduate students in Marchand's department has shrunk by $30 \%$.

Jessica Smith, a chemistry graduate student at Berkeley, says that ceiling leaks in labs have ruined experiments and machinery, although one leak was fixed by funnelling the water away using rubber tubing. "The biggest budget-related impediment to my research is our crumbling facilities," she says.

The cuts are also making it harder for the university to retain staff, says Jeffrey Bluestone, executive vice-chancellor of the University of California, San Francisco (UCSF), which relies on state contributions to pay faculty salaries and benefits, and so cannot match the packages at some private institutions. Losses include Didier Stainier, a geneticist who went to the Max Planck Institute for Heart and Lung Research in Bad Nauheim, Germany, and Christopher Voigt, a synthetic biologist who left UCSF this year for the Massachusetts Institute of Technology in Cambridge. "In a different world, we could have kept him," Bluestone says of Voigt.

More broadly, ongoing cuts will hamper the system's ability to nurture California's technology sector, "which is heavily reliant on bringing in talent from universities", says Douglass.

A report on the future of the University of California, released in November 2010, led campuses to increase enrolment of students from other states, who pay higher fees. Another fund-raising option, not yet adopted, is to allow the most prestigious campuses, such as Berkeley and Los Angeles, to charge higher tuition fees than the others. And in state elections next year, voters will probably be asked to consider boosting taxes, in part to fund higher education.

Douglass says that such measures are unlikely to reverse the major declines in state funding. The University of California must try to staunch the bleeding before its reputation as a successful alternative to costly private US universities is irreparably damaged. 